Lenise Vieira, ${ }^{1,2}$ Maria Buchuid ${ }^{3}$ and Elizabete Lucas ${ }^{1}$

\title{
THE INFLUENCE OF PRESSURE AND DISSOLVED GASES IN PETROLEUM ON THE EFFICIENCY OF WAX DEPOSITION INHIBITORS
}

\author{
${ }^{1}$ Institute of Macromolecules, Federal University of Rio de Janeiro, Ilha do Fundao, 21945-970, \\ Rio de Janeiro, Brazil \\ ${ }^{2}$ PETROBRAS Research Center, Ilha do Fundao, Q7, 21949-900, Rio de Janeiro, Brazil \\ lenise@petrobras.com.br \\ ${ }^{3}$ Gorceix Foundation, Ilha do Fundao, Q7, 21949-900, Rio de Janeiro, Brazil.
}

Received: March 26, 2008

\begin{abstract}
Evaluations of wax inhibitors carried out in laboratories are generally performed on stabilized oil samples, that is, without the presence of natural gas and at atmospheric pressure. Therefore, the effects of two important factors that influence wax solubility - the light fractions and temperature - are not considered, and the results may not reflect what really happens in production lines and facilities. This work evaluates the efficiency of two wax inhibitors based on ethylene copolymer and vinyl acetate, at four concentrations, in a sample of paraffin oil in the presence of light fractions and under pressure. The parameter employed in the evaluation was the wax appearance temperature (WAT), or the cloud point, determined by high-pressure differential scanning calorimetry. The gas used was a mixture of eight components and the tests were run at three pressures. In general, the inhibitors had little influence on the cloud point and a pronounced effect on the pour point and viscosity. In this case it was possible to observe changes in the WAT with both wax inhibitors in the tests conducted at atmospheric pressure up to 150 bar and in the presence of the multi-component gas mixture, suggesting that one of the mechanisms through which wax deposition inhibitors work is polynucleation.
\end{abstract}

Key words: high pressure $\mu \mathrm{DSC}$, viscosity, crude oil, paraffin, wax crystallization, deposition inhibitors.

\section{Introduction}

Problems referred to the wax crystallization and deposition occur at all stages of oil production. These problems range from damage of the producing formations to blockage of lines and processing equipment. The problems caused by precipitation of waxes, such as decreased flow rates, affect the efficiency of the processes involved and entail a substantial cost for control and remediation of wax deposits $[1,2]$.
To prevent wax deposition it is important to understand the nature of the waxes present in oil and the basic factors that affect their formation, mainly the changes in the oil composition with decreasing temperature and pressure, which are closely associated with all processes, from output to production and transport of petroleum [3, 4]. As a result, the solubility of the fractions of higher molar mass can be sufficiently reduced so that they reach the wax appearance point (WAT), or the cloud point, and cause precipitation of the waxes [5].

Various methods have been employed to prevent or remediate organic deposition problems in oil production/ transport facilities, including mechanical (e.g., scrapers, pigs), thermal (e.g., insulation, electrical heating, treatment with hot oil) and chemical (e.g., solvents, dispersants, inhibitors) [6]. The most suitable control method depends on the field production system and available facilities, and it is possible to use a combination of one or more methods.

Despite the efforts to mitigate wax deposition, these problems are still recurrent and the remediation costs are high, mainly in offshore systems. Therefore the best solution is to prevent first of all the formation of these deposits.

Wax inhibitors are typical polymers, such as polyacrylates, polymethacrylates and ethylene vinyl acetate (EVA) copolymers, among others. The mechanisms by means of which these wax inhibitors work are not fully known. A common viewpoint is that wax inhibitors that act as crystal modifiers are capable of being incorporated on the face of a growing crystal, interrupting the wax structure and changing the formation rate, thus reducing the tendency for formation of three-dimensional networks, with the consequent reduction of the pour point and viscosity [7]. The second inhibition mechanism is believed to be the creation of a large number of wax nuclei of subcritical size (polynucleation), where none or few of these nuclei can grow large enough to become stable. The third mechanism would be the reduction of the tendency 
of the crystals to attach to metal surfaces, such as pipe walls [8-11]. Probably the action of inhibitors is due to a combination of one or more of these mechanisms involving nucleation, co-crystallization and adsorption.

No inhibitor is universally effective, and therefore the use of a wax inhibitor always requires a selection process for the type of oil in question and a set of experiments under operating conditions [9].

The main aim of this work is to evaluate the effect of pressure and dissolved gases on the efficiency of two wax inhibitors based on the copolymer ethylene vinyl acetate (EVA), at four concentrations, on the wax appearance temperature of a paraffin petroleum. The systems were evaluated at three different pressures.

\section{Experimental}

\subsection{M aterials}

The stabilized oil sample, with a KUOP classification of 12 , i.e. paraffin, was kindly supplied by Petrobras. The characterization data of the oil sample and molar composition of the gases are presented in Tables 1 and 2, respectively. Two different commercial wax deposition inhibitors, called Inhibitor A and Inhibitor B, were used as a $5 \%$ solution.

Table 1

Oil characterization data

\begin{tabular}{|l|c|}
\hline \multicolumn{1}{|c|}{ Property } & Oil \\
\hline API density, $333 \mathrm{~K} / 333 \mathrm{~K}$ & 41.1 \\
\hline KUOP factor & 12.3 \\
\hline Pour point, $\mathrm{K}$ & 261.15 \\
\hline Wax content, mass \% & 3.7 \\
\hline
\end{tabular}

Table 2

Molar composition of the gases

\begin{tabular}{|c|c|}
\hline Component & Content in the oil, mol \% \\
\hline $\mathrm{N}_{2}$ & 0.58 \\
\hline $\mathrm{CO}_{2}$ & 0.88 \\
\hline $\mathrm{H}_{2} \mathrm{~S}$ & 0.00 \\
\hline $\mathrm{C} 1$ & 56.35 \\
\hline $\mathrm{C}_{2}$ & 17.06 \\
\hline $\mathrm{C}_{3}$ & 13.5 \\
\hline$i-\mathrm{C}_{4}$ & 2.76 \\
\hline$n-\mathrm{C}_{4}$ & 4.91 \\
\hline$i-\mathrm{C}_{5}$ & 1.28 \\
\hline$n-\mathrm{C}_{5}$ & 1.45 \\
\hline $\mathrm{C}_{6}$ & 0.82 \\
\hline $\mathrm{C}_{7}$ & 0.24 \\
\hline $\mathrm{C}_{8}$ & 0.12 \\
\hline $\mathrm{C}_{9}$ & 0.03 \\
\hline
\end{tabular}

\subsection{Pre-treatment of the oil samples}

Before running the tests, the oil sample was preheated at $353.15 \mathrm{~K}$ for one hour to completely solubilize the waxes.

\subsection{Differential scanning microcalorimetry - mDSC}

The analyses to determine the WAT without pressure were carried out in a SETARAM DSC IIIa differential scanning microcalorimeter, in $850 \mu \mathrm{L}$ sealed cells of Hastelloy alloy. The experiments were performed within the temperature range of $353.15-263.15 \mathrm{~K}$ at a cooling rate of $1 \mathrm{~K} / \mathrm{min}$. The additive concentrations were 100 , 300, 500 and $1000 \mathrm{ppm}$.

\subsection{High-pressure differential scanning microcalorimetry - $\mu$ DSC HP}

The analyses to determine the wax appearance temperature at high pressures were carried out in a SETARAM DSC VII differential scanning microcalorimeter, in high-pressure stainless steel cells with volume of $0.5 \mathrm{~cm}^{3}$. The composition of the multicomponent gas mixture is presented in Table 3. The injection of the gas mixture and pressurization of the cell containing the sample was done by means of a panel coupled to the device with the capacity for reaching pressures up to $400 \mathrm{bar}$. The pressurized samples were heated to $353.15 \mathrm{~K}$ and kept at this temperature for three hours, after which the system was cooled to 263.15 at the rate of $1 \mathrm{~K} / \mathrm{min}$. The same procedure was repeated three times. The tests were carried out at pressures of 50,100 and 150 bar and at an additive concentration of $1000 \mathrm{ppm}$.

Table 3

\section{Composition of the micro-component gas mixture}

\begin{tabular}{|c|c|}
\hline Component & mol \% \\
\hline Nitrogen & 0.56 \\
\hline Carbon dioxide & 0.61 \\
\hline Methane & 66.62 \\
\hline Ethane & 13.91 \\
\hline Propane & 11.33 \\
\hline$i$-Butane & 2.82 \\
\hline$n$-Butane & 4.08 \\
\hline$i$-Pentane & 0.03 \\
\hline$n$-Pentane & 0.03 \\
\hline
\end{tabular}




\subsection{Rheology}

The rheological figures were determined using a ThermoHaake RS1 rheometer with a DG43 sensor, employing the shear rate of $100 \mathrm{~s}^{-1}$ and the cooling rate of $0.005 \mathrm{~K} / \mathrm{s}$. The analyses were carried out within the temperature range of $353.15-280.15 \mathrm{~K}$ and at additive concentrations of $100,300,500$ and $1000 \mathrm{ppm}$.

\subsection{Pour point}

The tests were run using a Phase Technology PCA$70 \mathrm{X}$ pour and cloud point analyzer, whose operations are described in ASTM D5449. The procedure followed is described in the ASTM D97 standard. The additive concentrations were 100, 300, 500 and 1000 ppm.

\section{Results and Discussion}

\subsection{Pour point of the systems oil and oil + additive}

Table 4 shows the pour point results obtained for the systems. The pour point of the oil under study is $261.15 \mathrm{~K}$, meaning that this is the temperature at which the oil starts to flow under the action of gravity. The pour point test is very useful for pre-selection of organic deposition inhibitors when the results show a capacity to reduce the pour point, that is, in the presence of the additive the oil can be cooled to temperatures below its original pour point without interrupting the flow.

A comparison of inhibitors A and B shows that inhibitor B presents a discrete reduction of the pour point at the concentration of $100 \mathrm{ppm}$ (from 261.15 to $258.15 \mathrm{~K}$ ). At other concentrations, worse fluidity of the system can be observed at the action of the additive. On the other hand, inhibitor A causes a reduction in the pour point from 261.15 to $252.15 \mathrm{~K}$, with $300 \mathrm{ppm}$ of additive being sufficient to attain this result. This behavior suggests that inhibitor A is able to be incorporated on the face of growing crystals to change both their structure and growth rate, causing a reduced tendency for formation of the three-dimensional network, thus acting as a crystal modifier.

Table 4

Pour point of oil mixed with inhibitor $A$ and inhibitor $B$ at different concentrations

\begin{tabular}{|c|c|c|}
\hline \multirow{2}{*}{ Concentration, ppm } & \multicolumn{2}{|c|}{ Pour point, K } \\
\cline { 2 - 3 } & Inhibitor A & Inhibitor B \\
\hline 0 & 261.15 & 261.15 \\
\hline 100 & 261.15 & 258.15 \\
\hline 300 & 252.15 & 270.15 \\
\hline 500 & 252.15 & 267.17 \\
\hline 1000 & 252.15 & 261.15 \\
\hline
\end{tabular}

\subsection{Rheological behavior of the systems oil and oil + additive}

Figures 1 and 2 show the variation in the oil viscosity as a function of temperature in the systems containing different concentrations of inhibitor $\mathrm{A}$ and inhibitor B, respectively. Like the flow point test, a relatively simple and low-cost method, the rheological curve also supplies information concerning the fluidity of the system and can be used to evaluate additives as organic deposition inhibitors. In reality, tests on the variation of viscosity at the action of temperature reduction more suitably reproduce the conditions the oil is subjected to in the field, because the sample is constantly moving. The curves obtained agree with the pour point tests presented in Table 4, but provide additional information as well. Unlike the variation in pour point, the curves show that $100 \mathrm{ppm}$ of inhibitor A is already sufficient to reduce the oil viscosity when the systems are compared at the temperature

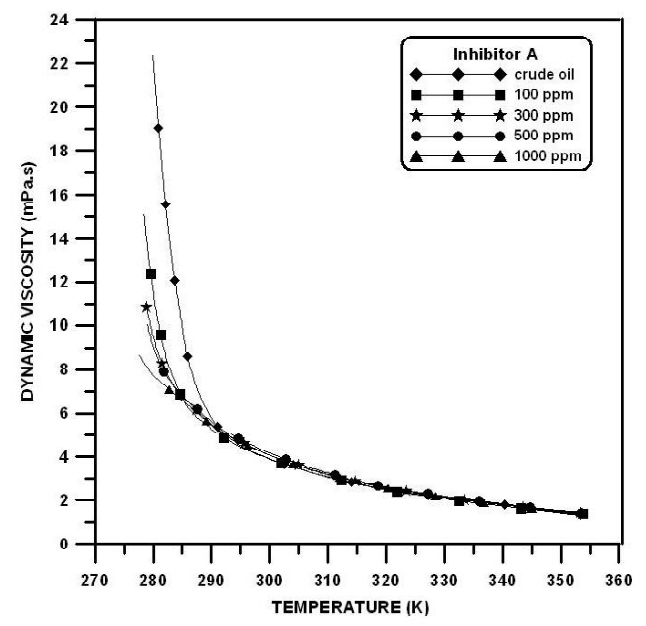

Fig. 1. Rheological behavior of crude oil and oil with different concentrations of inhibitor A

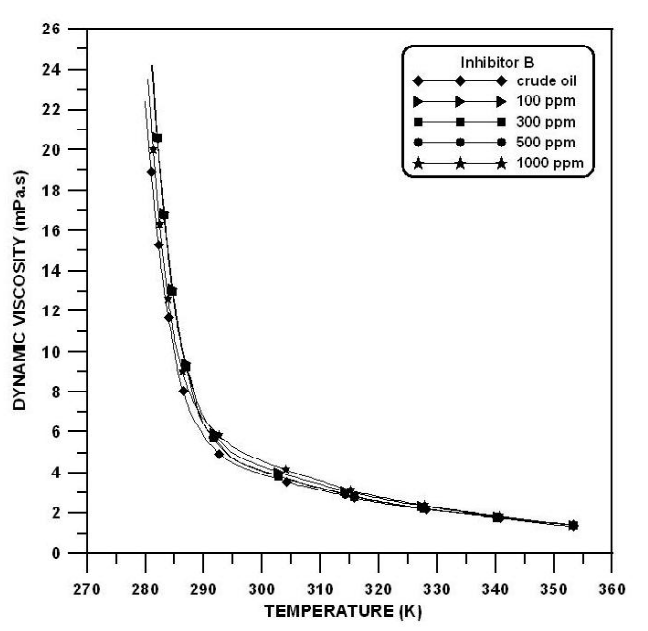

Fig. 2. Rheological behavior of crude oil and oil with different concentrations of inhibitor $\mathrm{B}$ 
of $283.15 \mathrm{~K}$. The viscosity values at this temperature for the other concentrations are very close to each other, which agree with the pour point results. For the system with inhibitor A added, the viscosity values, at the temperature of $283.15 \mathrm{~K}$, are much lower when compared with the crude oil.

The curves obtained with inhibitor B show its influence, already observed in the pour point test.

\subsection{Behavior of the wax appearance temperature (W AT)}

\subsubsection{Analysis without pressure}

The microcalorimetry curves as a function of the cooling rate $(1 \mathrm{~K} / \mathrm{min})$ obtained both for the crude oil and oil with different concentrations of inhibitor $\mathrm{A}$ and inhibitor B show two crystallization events. Each event is related to the crystallization of a group of waxes. The wax appearance temperature of each group appears to be related to the molar mass and structure of the chains: waxes that are more linear and have higher molar mass crystallize at higher temperatures while less linear waxes with lower molar mass crystallize at lower temperatures.

\section{Wax appearance temperature (WAT) of crude oil and oil plus additives - test conducted at atmospheric pressure}

\begin{tabular}{|c|c|c|c|c|}
\hline \multirow{2}{*}{$\begin{array}{c}\text { Additive } \\
\text { concentration, } \\
\text { ppm }\end{array}$} & \multicolumn{2}{|c|}{ Additive A } & \multicolumn{2}{c|}{ Additive B } \\
\cline { 2 - 5 } & WAt event & 2nd event & 1st event & 2nd event \\
\hline 0 & 316.25 & 294.81 & 316.25 & 294.81 \\
\hline 100 & 313.13 & 293.58 & 311.39 & 294.12 \\
\hline 300 & 310.96 & 292.62 & 309.3 & 293.53 \\
\hline 500 & 310.43 & 291.91 & 309.9 & 294.12 \\
\hline 1000 & - & 291.19 & 307.41 & 294.37 \\
\hline
\end{tabular}

Table 5 summarizes the results of two crystallization events being observed on the microcalorimetry curves. For the crude oil, there is a crystallization event at $316.25 \mathrm{~K}$ and another at $294.81 \mathrm{~K}$. Both inhibitor A and inhibitor B cause a reduction in the WAT of the first event, with the intensity of the reduction associated with the additive concentration. In the case of inhibitor $\mathrm{A}$, at an additive concentration of $1000 \mathrm{ppm}$ the first crystallization event never occurs, showing the additive capacity to inhibit the formation of this group of wax crystals. The second crystallization event, which occurs at $294.81 \mathrm{~K}$ in the crude oil, varies with the addition of inhibitor A and does not vary significantly with the addition of inhibitor B. These results, obtained without the effect of pressure, although containing less information detail, are in agreement with the results of the tests of pour point and variation in viscosity with temperature reduction. Table 5 summarizes the results of two crystallization events being observed on the microcalorimetry curves. For the crude oil, there is a crystallization event at $316.25 \mathrm{~K}$ and another at $294.81 \mathrm{~K}$. Both inhibitor A and inhibitor B cause a reduction in the WAT of the first event, with the intensity of the reduction associated with the additive concentration. In the case of inhibitor A, at an additive concentration of $1000 \mathrm{ppm}$ the first crystallization event never occurs, showing the additive capacity to inhibit the formation of this group of wax crystals. The second crystallization event, which occurs at $294.81 \mathrm{~K}$ in the crude oil, varies with the addition of inhibitor A and does not vary significantly with the addition of inhibitor B. These results, obtained without the effect of pressure, although containing less information detail, are in agreement with the results of the tests of pour point and variation in viscosity with temperature reduction.

\subsubsection{Analysis under pressure and addition of the gas mixture}

We also performed the microcalorimetry tests of the systems under pressure $(50,100$ and 150 bar) and in the presence of a mixture of gases, seeking to assess the influence of conditions similar to those under which oil production actually occurs on the efficiency results of organic deposition inhibitors. These tests were carried out only at an inhibitor concentration of 1000 ppm. Fig. 1 shows the $\mu$ DSC curves obtained under pressure of 50 bar, compared to the test conducted under pressure of 1.01 bar. It can be seen that the pressure variation in this case influences only the wax appearance temperature of the first event, shifting it to lower values. The temperatures associated with the second event remain practically unchanged. The result obtained for the first crystallization event of the crude oil without pressure and without gas mixture addition $(316.25 \mathrm{~K})$ was very similar to that obtained for the crude oil under 1.01 bar without the addition of the gas mixture $(314.40 \mathrm{~K})$, although they were carried out in two different equipments. These results indicate that those obtained by conventional techniques (pour point, viscosity and WAT without pressure and without addition of gases) show a more critical situation than under real conditions.

Table 6 summarizes the results obtained at varied pressures $(50,100$ and 150 bar). It can be seen that increased pressure leads to reduced WAT for the oil without additive and with inhibitors A and B as well. The same behavior was observed for two crystallization events. In the case of oil with inhibitor B added, pressures of around 100 bar and above caused the complete disappearance of the first crystallization event, evidencing the additive's action on the wax crystallization process.

The $\mu$ DSC results with pressure and addition of the gas mixture show more details of the wax crystallization processes, but they are coherent with those obtained by the other techniques, i.e. that inhibitor A appears to be more efficient than inhibitor B. 
Wax appearance temperature (WAT) of crude oil and oil with additives - test conducted at different pressures

\begin{tabular}{|c|c|c|c|c|c|c|}
\hline \multirow{2}{*}{$\begin{array}{c}\text { Pressure, } \\
\text { bar }\end{array}$} & \multicolumn{2}{|c|}{ Without additive } & \multicolumn{2}{c|}{ Additive A, 1000 ppm } & \multicolumn{2}{c|}{ Additive B, 1000 ppm } \\
\cline { 2 - 7 } & $\begin{array}{c}\text { 1st crystalli- } \\
\text { zation event, K }\end{array}$ & $\begin{array}{c}\text { 2nd crystalli- } \\
\text { zation event, K }\end{array}$ & $\begin{array}{c}\text { 1st crystallization } \\
\text { event, K }\end{array}$ & $\begin{array}{c}\text { 2nd crystallization } \\
\text { event, K }\end{array}$ & $\begin{array}{c}\text { 1st crystallization } \\
\text { event, K }\end{array}$ & $\begin{array}{c}\text { 2nd crystallization } \\
\text { event, K }\end{array}$ \\
\hline 1.01 & 314.40 & 295.64 & - & 291.96 & 305.88 & 293.90 \\
\hline 50 & 314.52 & 292.08 & - & 291.51 & 301.14 & 290.48 \\
\hline 100 & 300.76 & 286.01 & - & 281.51 & - & 287.82 \\
\hline 150 & 299.60 & 287.52 & - & 281.23 & - & 289.78 \\
\hline
\end{tabular}

The behavior observed by $\mu \mathrm{DSC}$ confirms the wax deposition inhibitors mechanism by polynucleation.

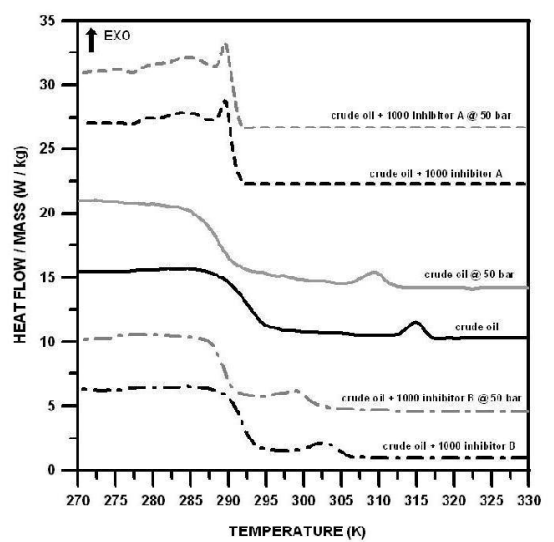

Fig. 3. $\mu \mathrm{DSC}$ curves for crude oil and oil with $1000 \mathrm{ppm}$ of inhibitors A and B at the pressure of 50 bar

\section{Conclusions}

The studies reported here show that the presence of dissolved gases in and pressure on petroleum increased the efficiency of the wax deposition inhibitors tested and can serve as a basis for optimizing the concentrations of the products to be employed. The use of a highly sensitive technique such as high-pressure differential scanning microcalorimetry also showed itself to be an important tool for confirming the action of these wax inhibitors by the polynucleation mechanism and enabled obtaining results under conditions closer to those actually existing in oil production lines.

\section{Acknowledgements}

The Brazilian Petroleum Company - Petrobras and The Brazilian Council for Scientific and Technological Development - CNPq.

\section{References}

[1] Bidmus H. and Mehrotra A.: Ind. \& Eng. Chem. Res., 2004, 43, 791 .
[2] Sadeghazad A. and Christiansen R.: $8^{\text {th }}$ Abu Dhabi International Petroleum Exhibition and Conference of the Society of Petroleum Engineers, 1998, SPE 49467, 11.

[3] Hansen A., Larsen E., Pedersen W. and Nielsen A.: Energy \& Fuel, 1991, 5, 914.

[4] Misra S., Baruah and Singh K: SPE Production \& Facilities, 1995, 50.

[5] Elsharkawy A., Al-Sahhaf T., Fahim M. and Al-Zabbai W.: SPE Latin American and Caribbean Petroleum Engineering Conference, 1999, SPE 54 006, 1.

[6] McClaflin G. and Whitfill D.: J. Petrol. Tech., 1984, SPE 12204, 1965.

[7] Machado A., Lucas E. and Gonzalez G.: J. Petrol. Sci. \& Eng., 2001, 32, 159.

[8] Pedersen K. and Rwnningsen H.: Energy \& Fuels, 2003, 17, 321 .

[9] Garcia M., Carbognan L., Urbina A. and Orea M.: Petrol. Sci. \& Tech., 1998, 16, 1001.

[10] Wang Kang-Shi., Wu Chien-Hou, CreeK J. et al.: Petrol. Sci. \& Tech., 2003, 21, 359.

[11] Marie E., Chevalier Y., Brunel S. et al.: J. Coll. Interface Sci., 2005, 290, 406.

\section{ВПЛИВ ТИСКУ І РОЗЧИНЕНИХ У НАФТІ ГАЗІВ НА ЕФЕКТИВНІСТЬ ІНГІБІТОРІВ ПАРАФІНОВИХ ВІДКЛАДІВ}

Анотація. У роботі під тиском та при чотирьох різних концентраціях проведено оцінку дії двох парафінових інгібіторів на основі кополімеру етилену і вінілацетату для парафінистої нафти, що містить світлі фракиії. Параметром оцінювання була температура появи парафіну (WАX), тобто температура помутніння, яка визначалась диференційною скануючою калориметрією під високим тиском. Використано газ, що складається з восьми компонентів. Дослідження проведені при трьох різних тисках. Встановлено, щьо інгібітори незначно впливають на температуру помутніння, але мають помітний вплив на температуру застигання та в'язкість. Встановлено, щзо зміни у WАX спостерігались для обох інгібіторів як при атмосферному тиску $і$ до 150 бар, так $і$ в присутності багатокомпонентної газової сумімі, що дозволяє припустити поліциклічний механізм дії інгібіторів.

Ключові слова: диференційна скануюча калориметрія під високим тиском, в'язкість, сира нафта, парафін, кристалізачія парафіну, інгібітори відкладів. 